高速液体クロマトグラフィーを用いた血鼎中 L-DOPA の定量*1

水谷義勝, 石津谷修; 岡田良樹 $* 2$, 小川道子*3

静岡労災病院薬剂部*2

同院神経内科*3

\title{
Determination of L-DOPA in Plasma by High Performance Liquid Chromatography*1
}

\author{
YoshiKatSU MIZUTANI, OSAMU ISHIZUYA, YoshIKI OKADA, ${ }^{2}$ \\ MICHICO OGAWA*3
}

\author{
Pharmacy, Shizuoka Rosai Hospital*2 \\ Department of Neurology, Shizuoka Rosai Hospital*3
}

(Received December 28, 1983)

\begin{abstract}
The L-DOPA levels in plasma were determined by high performance liquid chromatography. Separation of L-DOPA from plasma was achieved by alumina adsorption using tris-HCl buffer ( $\mathrm{pH}$ 8.6) without deproteinization. Adsorption of L-DOPA onto alumina showed liquid-solid equilibriums with constant rates at both adsorption and extraction steps. For this reason, the recovery of L-DOPA from plasma varied with alumina amounts, acidity and volume of the eluate used. Maximal recovery $(89 \%)$ was achieved when $50 \mathrm{mg}$ of alumina and $1 \mathrm{ml}$ of eluate of $1 \mathrm{M} \mathrm{AcOH}$ were used. Norepinephrine and epinephrine, as well as L-DOPA, were assayed by this method, and linear caribration curves were obtained as little as $2000 \mathrm{pg} / \mathrm{ml}$ for norepinephrine and epinephrine, and $5 \mu \mathrm{g} / \mathrm{ml}$ for L-DOPA. Reproducibility was demonstrated by a day-to-day coefficient of variation based on the change of assay value for standard plasma sample containing $1 \mu \mathrm{g} / \mathrm{ml}$ of L-DOPA. The day-to-day coefficient of variation was less than $4 \%$, and the within-run coefficient of variation was less than $3 \%$.

The interference by other probable catechols in plasma such as dopamine and carbidopa which is often administered with L-DOPA were not found. The method involving alumina extraction established in this study has general applicability in very accurately determining L-DOPA, norepinephrine and epinephrine in plasma.
\end{abstract}

Keywords_- high performance liquid chromatography; plasma; L-DOPA; norepinephrine; epinephrine; catecholamine; alumina adsorption; tris- $\mathrm{HCl}$ buffer; liquid-solid equilibriums

\section{粕}

L-DOPA は抗パーキンソン氏病薬として広く用いら れているが, 経口投与ではバイオアベイラビリティが低 く, 投与量, 個人差による血中レベルのバラツキが大き (.1 4) L-DOPA の血中レベルと臨床像との相関につい

*1 本報の一部は日本薬学会 103 年会（東京1983年） において発表.

*2,3 浜松市将監町 25; 25, Shogen-cho, Hamamatsushi, Shizuoka, 430 Japan
}

ては定説はなく，ある程度の相関を見い出した報告6 8) ああるが，長期投与による反応性の減弱”および副作用 の発現など未解明な面が残されている.

今回, 著者らは L-DOPA の血中レベルと臨床像との 相関をより詳細に研究する目的のため, まず血獎中の L-DOPA 濃度測定法を確立することを試みた．測定機 器としては高速液体クロマトグラフィー（HPLC）法を 用いたが，二，三の興味ある知見を得たので報告する. 


\section{实 䣯 の 部}

\section{1. 試菓および試料}

標準物質としての L-DOPA， ノルエピネフリン(NE), エピネフリン (E), およびその他の試薬はすべて市販の 特級品を用いた. 標準血漿は新鮮凍結血墏（血液センタ 一）をプールしたるのを，また前処理用のアルミナはW 200 neutral (INC) を Anton ${ }^{10)}$ の方法により活性化し たものを用いた.

\section{HPLC 条件}

装置：高速液体クロマトグラフ 635

検出器: 多波長 UV モ=ター 635-0900, 分光螢光光 度計 650-0010,トリヒドロキシインドール(THI) 用反 応システム 635

カラム：3013-C (弱酸性陽イオン交換カラム, 4.0\$ $\times$ $150 \mathrm{~mm}$ )

以上の装置はすべて日立製作所製である.

カラム温度 : $45^{\circ} \mathrm{C}$

移動相 : $0.1 \mathrm{M} \mathrm{KH}_{2} \mathrm{PO}_{4}-0.075 \% \mathrm{H}_{3} \mathrm{PO}_{4}(\mathrm{pH} 3.0)$

流速 $: 0.6 \mathrm{ml} / \mathrm{min}$

\section{3. 試料湥液の琱整}

ミニカラム（藤沢メディカルサプライ，CPK用）中に 血墏 $1 \mathrm{ml}, 10 \% \mathrm{Na}_{2} \mathrm{~S}_{2} \mathrm{O}_{5} 50 \mu \mathrm{l}, 0.5 \mathrm{M}$ 酢酸 $150 \mu \mathrm{l}, 1.5 \mathrm{M}$ トリスー塩酸㗔衝液 (2\% EDTA-2Na，pH 8.6) $1 \mathrm{ml}$, およびアルミナ $50 \mathrm{mg}$ を加え, 密栓をして10分間はげし く振とうした後, フルミナを蒸留水 $20 \mathrm{ml}$ で洗浄, 沪過 し， 2 分間遠心脱水 $(2500 \mathrm{rpm})$ した. 次にフィルター 部汭ャップをし，0.5〜1M 酢酸を $0.2 \sim 1 \mathrm{ml}$ 加光20分 間ボルテックス・ミキサーで筧扫後, 抽出液 $50 \mu \mathrm{l}$ を $\mathrm{H}$ PLCに注入した. なお, 以上の操作は室温下で行った.

\section{結果および考暴}

\section{HPLC 策件の検讨}

$0.1 \mathrm{M} \mathrm{KH}_{2} \mathrm{PO}_{4}$ にリン酸を加え移動相の $\mathrm{pH}$ を調整し, 標準物質 (L-DOPA, NE, E) のキャパシティ比 $\left(\mathrm{k}^{\prime}\right)$ に与える影響を調べた (Fig.1). この結果から移動相の $\mathrm{pH} 3.0\left(0.1 \mathrm{M} \quad \mathrm{KH}_{2} \mathrm{PO}_{4}-0.075 \% \quad \mathrm{H}_{3} \mathrm{PO}_{4}\right)$ 飞設定し た. L-DOPA，NE，E をそれぞれ $0.25 \mu \mathrm{g}$ 含有する0.5 M 眽酸 $50 \mu 1$ を HPLC に注入して得られたクロマトグ ラム (UV $280 \mathrm{~nm}$ ) では各ピークの分離が良好であった (Fig. 2).

\section{2. 标準物亚の検胃線および再現性}

L-DOPA を $0.5 \mathrm{M}$ 酢酸と溶解し, その $50 \mu \mathrm{l}$ 中にそ れぞれ $1,0.5,0.25,0.125,0.05,0.00125 \mu \mathrm{g}$ の LDOPA を含む試料を HPLC に注入した. 試料の量とピ

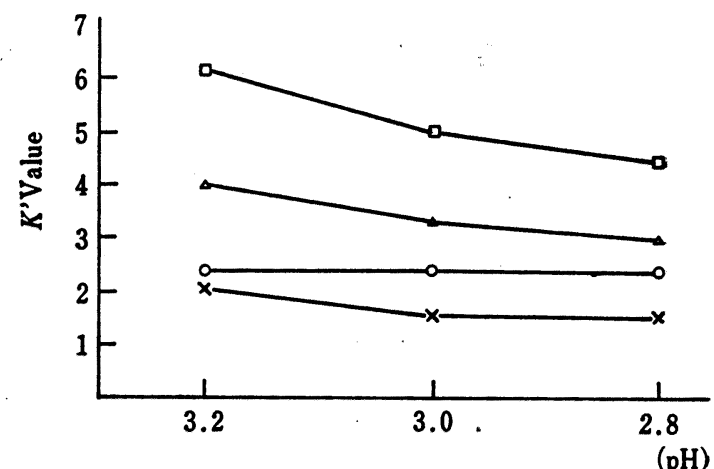

Fig. 1. Effect of $\mathrm{pH}$ of Mobil Phase on $\mathrm{k}^{\prime}$ Value of L-DOPA $(\mathrm{O}-\mathrm{O})$, Norepinephrine $(\triangle-\Delta)$, Epinephrine $(\square-\square)$ and $\mathrm{AcOH}(x-x)$ column: $3013-\mathrm{C}$, flow rate: $0.6 \mathrm{ml}$ / min, detect.:280nm, temp. $: 45^{\circ} \mathrm{C}$

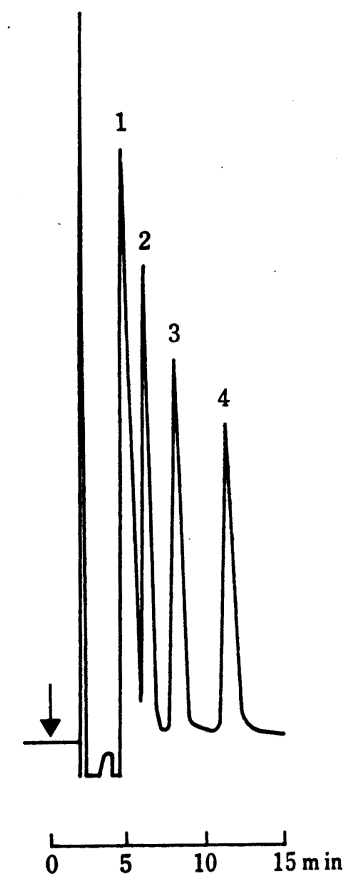

Fig. 2. Chromatogram of Catecholamines $1:$ AcOH $2:$ L-DOPA 3 : Norepinephrine $4:$ Epinephrine

HPLC conditions were the same as those in Fig. 1. mobil phase $: 0.1 \mathrm{M}$ $\mathrm{KH}_{2} \mathrm{PO}_{4}-0.075 \% \mathrm{H}_{3} \mathrm{PO}_{4}(\mathrm{pH} 3.0)$

一クの高さとの間には, UV 法 $(280 \mathrm{~nm})$, 螢光法 $(\mathrm{Ex}$ $280 \mathrm{~nm}, \operatorname{Em} 320 \mathrm{~nm})$, THI 法 (Ex410 nm, Em 510 $\mathrm{nm}$ ) の各検出法でそれぞれ良好な直線性が得られた。 UV 法の場合, 回帰式は $\mathrm{y}=0.0236 \mathrm{x}-0.00001$, 相関係 
数 $\mathrm{r}=0.999$ であった. $\mathrm{y}$ はピークの吸光度, $\mathrm{x}$ は注入 量 $(\mu g)$ を示す，定量は絶対検量線法を用いた。また $\mathrm{N}=10$ 亿㧍ける $0.5 \mu \mathrm{g}$ 試量のピークの高さの変動保数は 1.8\%であった.

\section{3. 血娽の前处理法}

NE およびEを除蛋白せずに測定した方法 ${ }^{11}$ に準し， トリスー塩酸緩衝液を用いて L-DOPA をアルミナに吸 着させる処理法を検討した.

1) アルミナへの吸着

濃度既知の L-DOPA を含む蒸留水 $1 \mathrm{ml}$ を検体とし てアルミナによる吸着処理を行った後, 水溶液の一部を 直接 HPLC に注入して残存 L-DOPA 濃度を測定した (Fig. 3).この結果からアルミナに対する L-DOPAの 吸着等温線は液一固平衡型の直線となり, 吸着俰数 ( ルミナ $1 \dot{\mathrm{mg}}$ 中の L-DOPA 量) / (水溶液 $1 \mathrm{ml}$ 中の LDOPA 量) は0.9であった. なお，吸着試験はすへて室 温下で行った.

\section{2）アルミナからの抽出}

L-DOPA を吸着したアルミナからの抽出操作では, 回収率が抽出液量に依存する傾向がみられた，そこで L-DOPA を含まない蒸留水検体を処理したフルミナに 濃度既知の L-DOPA を含んた $0.5 \mathrm{M}$ 酢酸を加え, 室温 下 20 分間㩧汼後, L-DOPA の残存濃度を測定して抽出 時に㧍けるアルミナへの再吸着を検討した. 抽出液 (0.5 M 酢酸) が $0.2 \mathrm{ml}$ の場合, アルミナ量の增加に伴い吸 着は增加した (Fig. 4). しかし一定量のアルミナ（50

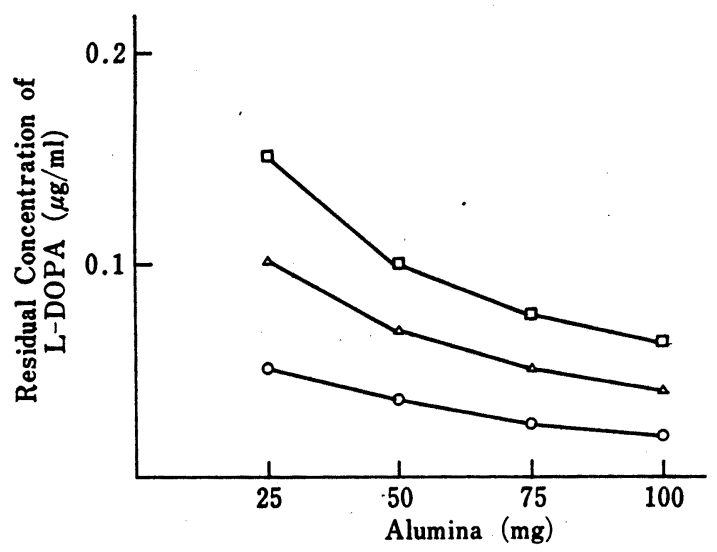

Fig. 3. Relationship between Alumina Amounts and Residual Concentration of L-DOPA in Aqueous Solution (pH 8.5) at Adsorption Step

Initial concentration of L-DOPA $0.5 \mu \mathrm{g} /$ $\mathrm{ml}(\mathrm{O}-\mathrm{O}), 1 \mu \mathrm{g} / \mathrm{ml}(\triangle-\triangle)$ and 1.5 $\mu \mathrm{g} / \mathrm{ml}(\square-\square)$.

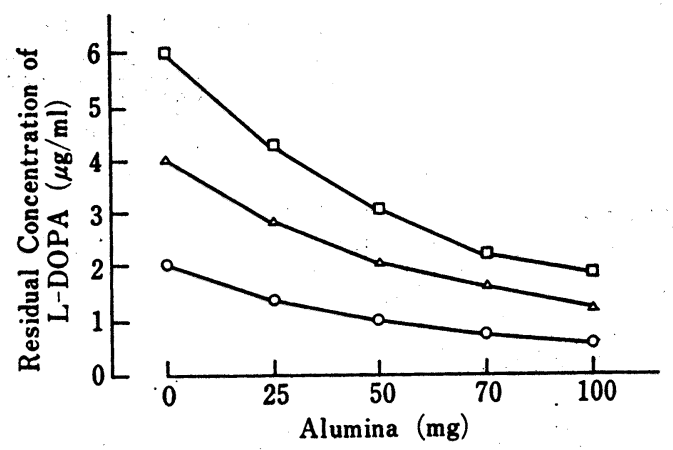

Fig. 4. Relationship between Alumina Amounts and Residual Concentration of L-DOPA $0.2 \mathrm{ml}$ of $0.5 \mathrm{M} \mathrm{AcOH}$ at Extraction Step Initial concentration of L-DOPA $2 \mu \mathrm{g} /$ $\mathrm{ml}(\mathrm{O}-\mathrm{O}), 4 \mu \mathrm{g} / \mathrm{ml}(\triangle-\triangle)$ and $6 \mu \mathrm{g} /$ $\mathrm{ml}(\square-\square)$.

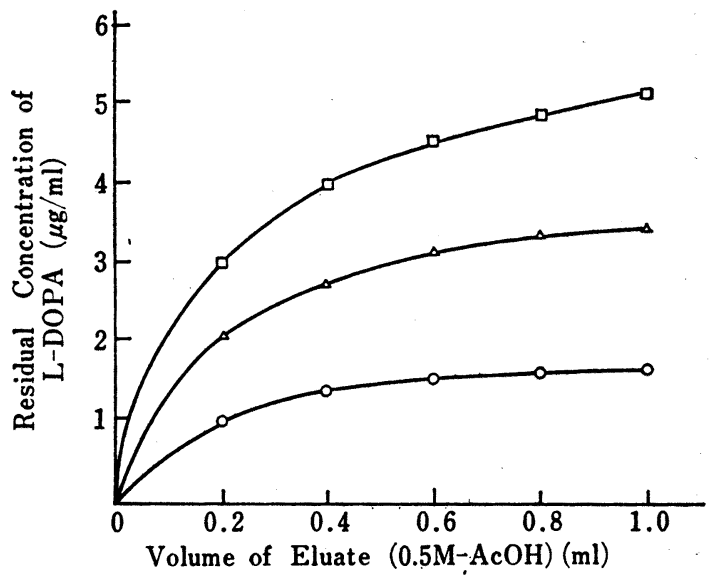

Fig. 5. Relationship between Volume of Eluate (0.5M AcOH) and Residual Concentration of L-DOPA at Extraction Step Initial concentration of L-DOPA $2 \mu \mathrm{g} /$ $\mathrm{ml}(\mathrm{O}-\mathrm{O}), 4 \mu \mathrm{g} / \mathrm{ml}(\triangle-\triangle)$ and $6 \mu \mathrm{g} /$ $\mathrm{ml}(\square-\square)$, the amounts of alumina were $50 \mathrm{mg}$.

$\mathrm{mg}$ ）に対しては抽出液量の増加に伴い吸着は減少した (Fig. 5). これらの結果より抽出時に拉ける液一固平衡 型の再吸着現象 (吸着係数 0.004) が示唆された.

3）標準血獎からの L-DOPA の回収率

前処理操作に打いて, 標準血奬と蒸留水との間に回収 率の差はなく, 血墏の処理中にも液 - 固平衡型の吸着が 保持されることが推察された. 回収率 $\mathrm{Y}(\mathrm{Y}=1$ で100\%) は次式で表わすことができた。

$$
\mathrm{Y}=\mathrm{Ka} \cdot \mathrm{X} \cdot \mathrm{Ve} /(\mathrm{Ka} \cdot \mathrm{X}+\mathrm{Va})(\mathrm{Ke} \cdot \mathrm{X}+\mathrm{Ve})
$$

ここで $\mathrm{Ka}, \mathrm{Ke}$ は吸着および抽出時に㧊ける吸着係 
Table 1. Ka and $\mathrm{Ke}$ of Alumina for L-DOPA

\begin{tabular}{lccc}
\hline \multicolumn{1}{c}{ Products } & Mesh & $\mathrm{Ka}^{*}(\ell / \mathrm{g})$ & $\mathrm{Ke}^{* *}(\ell / \mathrm{g})$ \\
\hline $\begin{array}{l}\text { Alumina W-200 } \\
\text { neutral (ICN) }\end{array}$ & 200 & 0.9 & 0.004 \\
$\begin{array}{l}\text { Alumina for } \\
\text { Catecholamine } \\
\text { (Wako) }\end{array}$ & $\begin{array}{r}\text { 100 100(40\%) } \\
145 \sim 200(20 \%)\end{array}$ & & \\
\hline$*$ pH 8.5 & & & \\
$* * 0.5 \mathrm{M}-\mathrm{AcOH}$ & & & \\
\end{tabular}

数 $(\ell / \mathrm{g}), \mathrm{Va}, \mathrm{Ve}$ は吸着試料および抽出液の容量 $(\mathrm{ml})$,

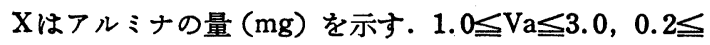
$\mathrm{Ve} \leqq 1.0,50 \leqq \mathrm{X} \leqq 100$ の各条件下において実測の回収率 はY式の値と一致し, 検量線は血墏中濃度として $5 \mu \mathrm{g} /$ $\mathrm{ml}$ 以下で原点を通る直線となった。

$1 \mathrm{M}$ 酢酸で抽出を行うと $\mathrm{Ke}$ が 0.0011 と低值を示し 回収率は向上したが，クロマトグラム上で NE とEの分 離能が低下した。

4) アルミナと L-DOPA の吸着係数

アルミナ W 200 neutral (ICN) と活性アルミナ（カ テュールアミン測定用）（和光純薬）の 2 種類のアルミ ナについて, Ka, Ke を測定した (Table 1). 両者間に みられる差異は主に単位重量あたりの表面積に依存して おり吸着特性は同じと考えられた。

\section{4. 測定精度}

前処理にアルミナ $50 \mathrm{mg}$ を用いて L-DOPA を吸着さ せ, $0.5 \mathrm{M}$ 酢酸 $0.2 \mathrm{ml}$ で抽出した場合と $1 \mathrm{M}$ 酢酸 $1 \mathrm{ml}$ で抽出した場合で，回収率はそれぞれ47\%と89\%を示し た. L-DOPA $1 \mu \mathrm{g}$ を含有する $1 \mathrm{ml}$ の血墏を 7 日毎に16 週間測定した結果, 両抽出法による測定值はともに変動 係数が within-run で 3\%以下, day-to-day で $4 \%$ 以 下と良好であった。

\section{L-DOPA， NE，E の同時測定}

HPLC の検出器に THI システムを用いることにより 血漿中の $\mathrm{NE}, \mathrm{E}$ を L-DOPA と同時に測定することが 可能であった. 前処理には $50 \mathrm{mg}$ のアルミナを用い 0.5 $\mathrm{M}$ 酢酸 $0.2 \mathrm{ml}$ で抽出を行った. 血獎中濃度として LDOPA が $5 \mu \mathrm{g} / \mathrm{ml}$, NE とEが $2000 \mathrm{pg} / \mathrm{ml}$ 以下ではそ れぞれ回収率が $47 \% ， 80 \% ， 80 \%$ と一定であり検量線は 直線性を示した。また, 検出限界 $(\mathrm{S} / \mathrm{N}=2)$ は血漿中濃 度としてそれぞれ $1 \mathrm{ng} / \mathrm{ml}, 40 \mathrm{pg} / \mathrm{ml}, 20 \mathrm{pg} / \mathrm{ml}$ に相当 した.

\section{6. 測定妨客物梊}

血漿およびアルミナからの夾雑物はクロマトグラム 上, $\mathrm{k}^{\prime}<1.5$ に現れた。 L-DOPA と併用されることの多 い carbidopa および遊離 dopamine は同じく $\mathrm{k}^{\prime}>4$ に

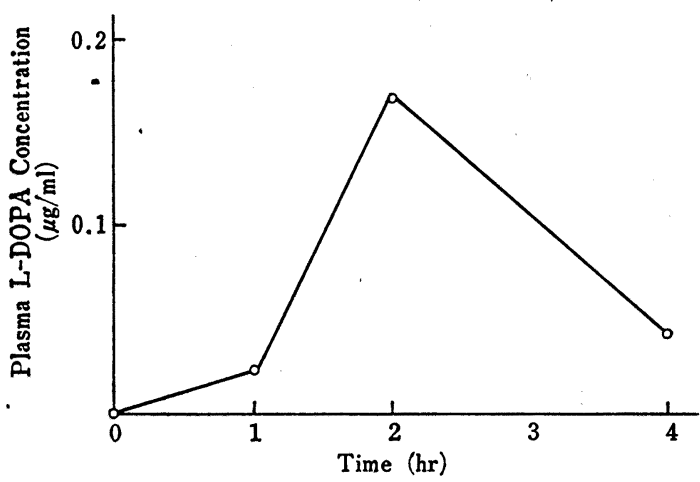

Fig. 6. Plasma Concentration Curve of L-DOPA after Oral Administration (200mg tablet) to Normal Subject

現れた.このことより本法はこれらの構造類似物質によ り妨害をらけないことが確かめられた。

7. 健常成人におけるモニタリング

健常成人男子（37歳）1名に対して市販の L-DOPA $200 \mathrm{mg}$ 錠を空腹時経口投与し，血墏中濃度を测定した (Fig. 6). 投与後 2 時間で $0.17 \mu \mathrm{g} / \mathrm{ml}$ のピークがみら れ，4時間後にはほとんど消失しており大本らの報告 ${ }^{12)}$ と同様の結果を得た。

\section{結論}

今回報告した血漿中 L-DOPA 濃度測定法は前処理に 除蛋白操作を要さず, 回収率, 測定精度についてす満足 な值が得られた. また, 本法の前処理法は多くのカテュ 一ル化合物の血漿中濃度測定に応用が可能であると考え られる。

謝辞 本研究に際し, carbidopa 標準品を提供された 三共株式会社に深謝いたします.

\section{文解}

1) D. B. Calne : Clin. Pharm. Therp., 11, 789 (1970).

2) T. J. Crow, I.G. Grove-White: Brit. J. Pharmacol., 43, 464 (1971).

3) G. Curzon, B.D. Kantamanemi, J. Trigwell: Clin. Chim. Acta, 37, 335 (1972).

4) T.A. Hare, B.L. Beasly: Chim. Acta., 45, 273 (1973).

5) K. Imai, M. Sugiura: Chem. Pharm. Bull., 20, 759 (1972).

6) I. Shoulson, G.A. Glaubiger, T.N. Chase: Neurology, 25, 1144 (1975).

7) R.D. Sweet, F.H. Mcdowell: Neurology, 24, 953 (1974). 
8) E.S. Tolsa, W.E. Martin, H.P. Cohen, R. L. Jacobson: Neurology, 25, 177 (1975).

9) C.D. Marsden, J.D. Parkes: Lancet, 1, 345 (1977).

10) A.H. Anton, D.F. Sayre: J. Pharmacol. Exp.
Ther., 138, 360 (1962).

11) P. Hjemdah, M. Daleskog, T. Kahan: Life Science, 25, 131 (1979).

12）大本堯史, 難波真平, 岸川秀実：基礎と臨床, 10. 507 (1979).

\section{等張で200Cal/L補給できる維持液}

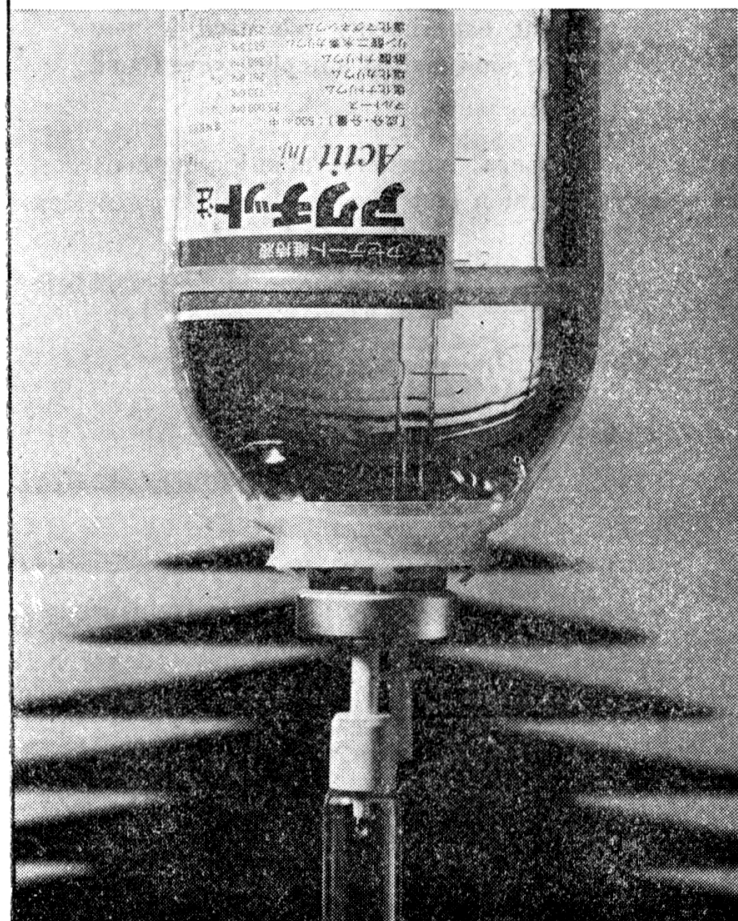

アセテート維持液

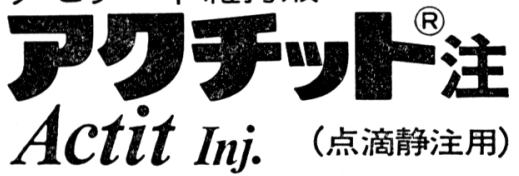

○塩基源としての酢酸ナトリウムは、肝よりも筋 肉およびその他の末梢組織において代謝され、 かつ、乳酸ナトリウムとは異る代謝経路により速 やかに代謝され塩基源として有効に作用します。 ・マルトースはインスリン依存性が少く、非経口 投与の場合、糖尿病及び糖尿病状態時(外科的 糖尿病)にもよく利用され、従来の $5 \mathrm{~W} / \mathrm{V} \%$ 糖加 維持液と同様に1も当り200Calの熱量補給が可 能です。

*用法・用量,使用上の注意等は製品添付文書をこ参照下さい。

健保適用

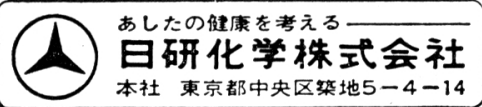

